\title{
Radium Beam Therapy and High-Voltage X-Rays*
}

\author{
By Prof. A. S. Eve, C.B.E., F.R.S., and L. G. Grimmett, \\ Radium Beam Therapy Research, London
}

$\mathrm{T}$ HE quantity of radium now employed in the treatment of cancer, by the 'beam' method alone, exceeds $120 \mathrm{gm}$., with a value in excess of $£ 800,000$. The Continental names for this method are telecurietherapie and Radiumfernbestrahlung, while 'radium beam therapy' is the

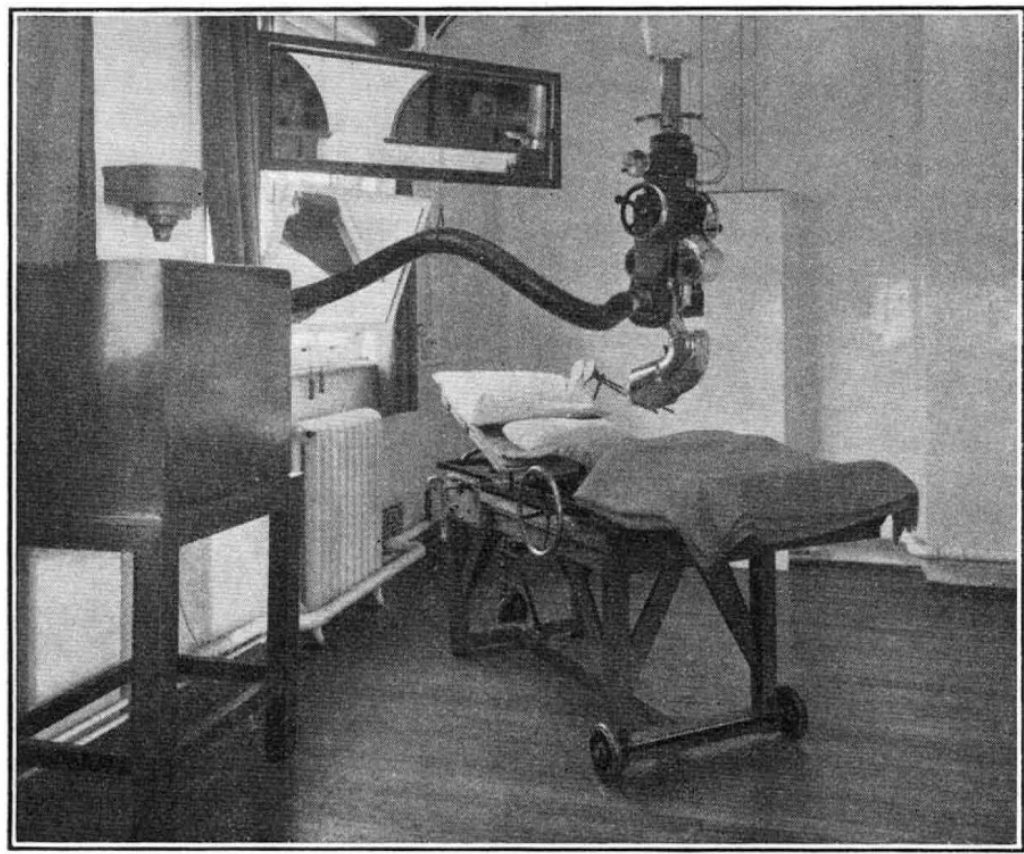

Fig. 1.

The latest 5 gm. Radium unit of the Radium Beam Therapy Research, LONDON. THE RADIUM CAPSULE IS TRANSFERRED PNEUMATICALLY TO AND FROM THE LEAD STORAGE-SAFE TO THE UNIT, WHERE THE GAMMA RADIATION IS canalized by a mass of dense tungsten alloy. The beam can be ORIENTATED IN ANY DESIRED DIRECTION BY SCREW ADJUSTMENTS, AND THE DOSAGE CAN BE MEASURED AT ANY POINT.

term commonly used in Great Britain. In this method of treatment a considerable quantity of radium (2-10 gm.) is surrounded by a large mass of lead or of tungsten alloy, and a beam of gammarays passes from the radium through a hole or window in the lead and is directed at the tumour or glands as may be desirable. A typical modern apparatus is shown in the photograph (Fig. 1).

In Table 1 is a list of institutions which are equipped for radium beam treatment.

One of the most complete radiation institutes is that recently built at Stockholm with funds

* This article has been published with the approval of the Executive Committee of the Radium Beam Therapy Researeh, on bebalf of which we are glad to acknowledge the generous loan of $10 \mathrm{gm}$. of radium by the Union Minière du Haut Katanga. collected to celebrate the jubilee of King Gustav V. It is a building of five stories, measuring about $170 \mathrm{ft}$. $\times 190 \mathrm{ft}$., well provided with radium and $\mathrm{X}$-ray apparatus, together with all modern conveniences for examining, treating and nursing patients. There are arrangements for keeping records of all cancer cases in Sweden. The institute has an able staff of therapists, pathologists and physicists, and the whole organization is part of the new University Hospital at Stockholm. Any country de. sirous of establishing an efficient radiological institute would do well to study the Swedish scheme. A full description of the building is given in a booklet published by Norstedt and Söner, Stockholm.

A great weakness of radium beam therapy in the past has been thelack of a good system of dosage units. Now, however, thanks to the physical research of the last few years, it has become possible to express gamma-radiation in the international 'röntgen' or $r$ unit, already so well established in X-ray therapy. The röntgen $(r)$ is that quantity of radiation which, when secondary electrons are fully utilized, and wall effects avoided, produces ionization in air at $0^{\circ} \mathrm{C}$. and $760 \mathrm{~mm}$. mercury pressure, such that one electrostatic unit of charge per cubic centimetre is liberated at saturation current. The unification of $\mathbf{X}$ - and gamma-ray dosage units is a great step forward, and will hasten the solution of many of the controversial problems of radiology.

It is of the utmost importance that the beam of rays shall be suitably directed, that the dosagerate at any particular part of the tumour or glands shall be known, and that the dosage shall be repeatable, or modified at will to any desired degree that experience may dictate. These purely physical problems have now been solved, and there is no longer any excuse for slipshod or haphazard treatment. 
In planning for the future, it is impossible to ignore the rival claims of radium and X-rays. Many radiologists believe that gamma-ray therapy is superior to X-ray therapy in its biological effects, and they attribute this superiority to the shorter wave-length of the gamma-rays; encouraged by this belief, they are striving after X-rays generated at higher and higher voltages, which approach the gamma-rays of radium in their nature. While there are many who would contest this point of view vigorously, yet since it is the motive which prompts the building of high-voltage $\mathrm{X}$-ray plants, we may be permitted, without entering into a discussion of such controversial points, to inquire how far an X-ray tube working at, let us say, 1 million volts is capable of imitating the radiation emitted by radium.

TABLe 1.

\begin{tabular}{|c|c|c|c|}
\hline Country & Institution & $\begin{array}{l}\text { Quantity } \\
\text { of radium }\end{array}$ & $\begin{array}{l}\text { Number } \\
\text { of units }\end{array}$ \\
\hline $\begin{array}{l}\text { Great Britain } \\
\text { Hungary } \\
\text { Norway } \\
\text { Sweden } \\
\text { U.S.A. }\end{array}$ & $\begin{array}{l}\text { Municipality of Vienna } \\
\text { Institut Radium, Bogota } \\
\text { Toronto Hospital } \\
\text { British Columbia Cancer } \\
\text { Foundation, Vancouver } \\
\text { Institut de Radium, Paris } \\
\text { Centre de Strasbourg } \\
\text { Centre de Lille } \\
\text { Institut de Radium, Ville- } \\
\text { juif } \\
\text { Centre de Bordeaux } \\
\text { Centre de Lyon } \\
\text { Radium Beam Therapy } \\
\text { Research, London } \\
\text { Cancer Hospital, London } \\
\text { Westminster Hospital, } \\
\text { London } \\
\text { Municipalité de Budapest } \\
\text { Norske Radiumfond } \\
\text { Radiumhemmet } \\
\text { Michael Reese Hospital, } \\
\text { Chicago } \\
\text { Belle-Vue Hospital, New } \\
\text { York } \\
\text { Memorial Hospital, New } \\
\text { York } \\
\text { American Oncological } \\
\text { Hospital, Philadelphia } \\
\text { New York Institute for } \\
\text { the Study of Malignant } \\
\text { Disease, Buffalo } \\
\text { Veterans Bureau } \\
\text { Dr. Williams Cameron, } \\
\text { New York }\end{array}$ & $\begin{array}{c}\text { gm. } \\
3 \\
4 \\
4 \\
3 \cdot 5 \\
11 \\
8 \\
6 \\
5 \\
4 \\
3 \\
10 \\
5 \\
4 \\
4 \\
3 \\
8 \\
6 \\
6 \\
5 \\
4 \\
4 \\
4 \\
4 \\
4 \\
2\end{array}$ & $\begin{array}{l}1 \\
1 \\
1 \\
1 \\
2 \\
2 \\
2 \\
1 \\
1 \\
1 \\
2 \\
1 \\
1 \\
1 \\
2 \\
2 \\
2 \\
1 \\
1 \\
1 \\
1 \\
1 \\
1 \\
1\end{array}$ \\
\hline
\end{tabular}

The nature of the radium spectrum has been known for a long time. It consists of a small number of sharp monochromatic 'lines' with energies ranging from a few kilovolts up to $2 \cdot 2$ million volts. They are represented in Fig. 2 by a number of vertical lines the heights of which are proportional to the intensity of the radiations. These data have been taken from "Radiations from Radioactive Substances" by Rutherford, Chadwick and Ellis, in conjunction with the latest values of the photoelectric coefficients.

An X-ray tube working at 1 million volts yields a continuous spectrum with a sharply defined short-wave limit at 1 million volts. The bulk of the radiation output corresponds to a voltage considerably less than 1 million volts. No data have as yet been published on the spectral distribution obtained with high-voltage $\mathrm{X}$-ray tubes, but we can obtain some idea of its nature by extrapolating Kramer's law, which holds very well for lower voltages of the order $100 \mathrm{kv}$. According to Kramer's law, the energy in the continuous spectrum which is included between the frequencies $\nu$ and $(\nu+d \nu)$ is given by:

$$
I d \nu=\frac{8 \pi}{3 \sqrt{3 l}} \times \frac{e^{2} h}{m c^{3}} \times Z\left(\nu_{0}-\nu\right) d v ;
$$

where $v_{0}$ is the frequency of the short-wave limit, $l$ is a numerical factor of order $6, Z$ the atomic number of the target, and the remaining symbols have the usual significance. If we fix the material of the target, and change the variable from the frequency $v$ to the wave-length $\lambda$, we may write :

$$
I_{\lambda}=\text { const. } V^{2}\left(V_{0}-V\right) \text {; }
$$

where $V_{0}$ is the maximum voltage applied, and $V$ is the voltage corresponding to the wavelength $\lambda$. The relative values of $I_{\lambda}$ calculated in this way for the unfiltered radiations are given in Table 2, together with the relative values of $I_{\lambda}$ after filtration with $1 \mathrm{~mm}$. and $2 \mathrm{~mm}$. lead. The latest available absorption data of Read and of Jones have been used in calculating the transmission through the filters.

TABIE 2.

Probable Energy Distribution in Continuous Spectrum of a Million-

\begin{tabular}{|c|c|c|c|c|}
\hline \multirow{2}{*}{ Wave-length } & \multirow{2}{*}{$\begin{array}{l}\text { Equivalent } \\
\text { Voltage }\end{array}$} & \multicolumn{3}{|c|}{ Relative Intensities $I_{\lambda}$} \\
\hline & & Unfiltered & $1 \mathrm{~mm} . \mathrm{Pb}$ & $2 \mathrm{~mm} . \mathrm{Pb}$ \\
\hline $\begin{array}{l}12 \cdot 35 \mathrm{X} . \mathrm{C} . \\
13 \cdot 0 \\
13 \cdot 8 \\
14 \cdot 5 \\
15 \cdot 4 \\
16 \cdot 5 \\
17 \cdot 6 \\
19 \cdot 0 \\
20 \cdot 7 \\
22 \cdot 5 \\
24 \cdot 6 \\
30 \cdot 8 \\
41 \cdot 1 \\
49 \cdot 3 \\
61 \cdot 5 \\
82 \cdot 2 \\
123 \cdot 5\end{array}$ & $\begin{array}{c}\text { kilovults } \\
1000 \\
950 \\
900 \\
850 \\
800 \\
750 \\
700 \\
650 \\
600 \\
550 \\
500 \\
400 \\
300 \\
250 \\
200 \\
150 \\
100\end{array}$ & $\begin{array}{c}0 \\
452 \\
810 \\
1080 \\
1280 \\
1410 \\
1470 \\
1480 \\
1440 \\
1370 \\
1250 \\
960 \\
630 \\
470 \\
320 \\
19 \cdot 1 \\
9\end{array}$ & $\begin{array}{r}0 \\
407 \\
725 \\
961 \\
1140 \\
1240 \\
1290 \\
1280 \\
1240 \\
1160 \\
1040 \\
745 \\
405 \\
243 \\
111 \\
2 \cdot 1 \\
0 \cdot 2\end{array}$ & $\begin{array}{r}0 \\
387 \\
645 \\
855 \\
1000 \\
1100 \\
1120 \\
1120 \\
1060 \\
990 \\
870 \\
580 \\
260 \\
128 \\
29 \\
2 \cdot 3 \\
-\end{array}$ \\
\hline
\end{tabular}
volt X-ray Tube, based on Kramer's Law,

The three curves corresponding to no filter, and filters of $1 \mathrm{~mm}$. and $2 \mathrm{~mm}$. lead respectively, are drawn, together with the radium spectrum, in Fig. 2. The great disparity between the radium spectrum and that of the million-volt $\mathrm{X}$-ray tube is evident. The peak of the Xradiation output occurs at a value between 600 and 700 kilovolts. There is very little radiation at 1 million volts and nothing at all beyond this value. On the other hand, a considerable portion of the radium spectrum is located above 1 million 
volts, with a particularly intense line at $\mathbf{1} \cdot 8$ million volts. To generate radiation comparable in quality with the gamma-rays of radium a voltage approaching 3 million would be required! Assuming that the engineering difficulties were overcome, it is not certain that electrons driven by 3 million volts on to a target would expend all their energy in the production of röntgen rays, as other transmutations might take place.

The greater energy emitted by an X-ray tube is of some advantage. It is not difficult to make an $\mathrm{X}$-ray tube the output in ergs of which is equivalent to that from some hundreds of grams of radium. water, at a distance of $10 \mathrm{~cm}$. below the surface for various kinds of radiation at different distances from the surface.

TABLE 3 .

Deptl Doses Measured in Water.

\begin{tabular}{|c|c|c|c|}
\hline Radiation source & Filter & $\begin{array}{l}\text { Distance } \\
\text { from surface }\end{array}$ & $\begin{array}{l}\text { Percentage } \\
\text { depth dose } \\
10 \mathrm{~cm} \text {. below } \\
\text { surface }\end{array}$ \\
\hline $\begin{array}{l}\text { X-rays, } 370 \mathrm{k} . v . \\
\text { X-rays, } 200 \mathrm{k.v} \\
\text { Radium point } \\
\text { source } \\
\text { Radium point } \\
\text { source }\end{array}$ & $\begin{array}{l}5.5 \mathrm{~mm} \text {. Cu. } \\
0.5 \mathrm{~mm} \text { C'u. } \\
0.5 \mathrm{~mm} . \text { Pt. } \\
0.5 \mathrm{~mm} . \text { Pt. }\end{array}$ & $\begin{array}{l}75 \mathrm{~cm} . \\
75 \mathrm{~cm} . \\
5 \mathrm{~cm} . \\
75 \mathrm{~cm} .\end{array}$ & $\begin{array}{l}43 \text { per cent } \\
36 \\
11 \\
58 \quad]\end{array}$ \\
\hline
\end{tabular}

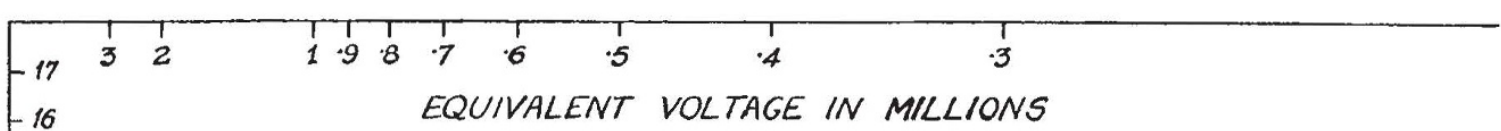

\begin{tabular}{l}
-16 \\
-15 \\
\hline \\
\hline \\
\hline \\
\hline
\end{tabular}

EQUIVALENT VOLTAGE IN MILLIONS

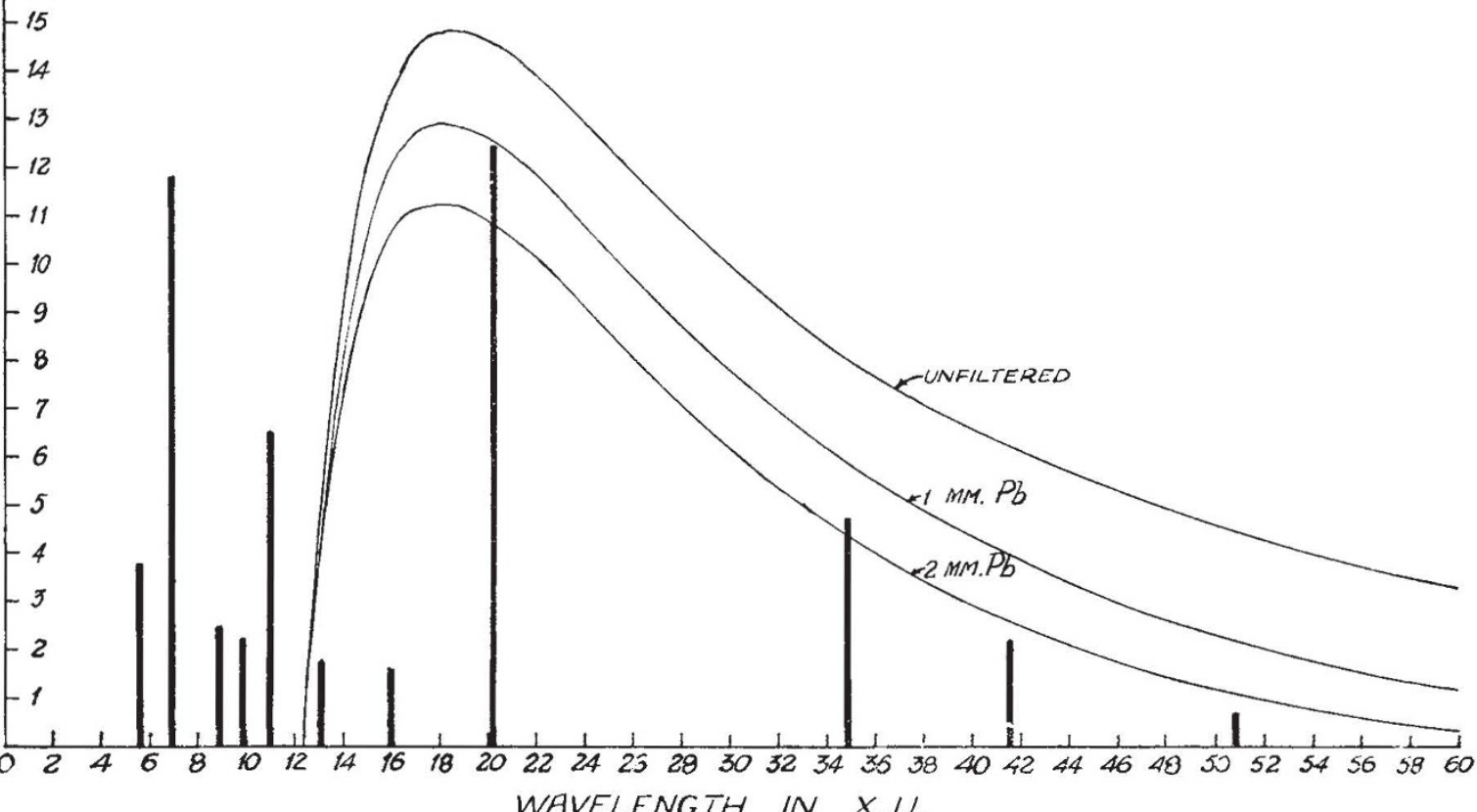

Fig. 2.

COMPARISON OF THE GAMMA-RAY LINE SPECTRUM OF RADIUM WITH THE CONTINUOUS SPECTRUM FROM A MILIION VOLT X-RAY TUBE, CALCULATED ACCORDING TO KRAMER'S LAW, FOR DIFFERENT FILTRATIONS.

This allows the tube to be used at a distance of 1-2 metres from the patient's skin, giving a prartically parallel beam resulting in a high 'depth dose', that is, a high ratio between the tumourdose at a depth, and the surface-dose on the skin. For it must be remembered that the skin reaction is the limiting factor in treatment. With the relatively small quantities of radium which are available for beam treatment, it is necessary to work with the radium sources so close to the skin as $5-10 \mathrm{~cm}$. in order to obtain intensities capable of producing biological effects. This results in a strongly divergent beam, and a poor depth-dose. This point is well illustrated in Table 3 , which gives the percentage depth-dose, as measured in
We thus have the paradoxical situation that the more penetrating radiation appears to penetrate less. The fact is that both radium and X-ray treatments are governed by the inverse square law, and that the superior penetrating power of gamma-rays cannot be exploited unless prohibitive quantities of radium are available to make it possible to work with large radium-skin distances (cf. last line of Table 3). Even radiologists them. selves are apt to lose sight of this important point and often stress, unduly and erroneously, the high penetration of gamma-rays.

The true advantage of radium treatment would therefore seem to depend on the property that a great part of the electromagnetic waves proceeding 
from radium are shorter in wave-length than those that emerge from any $X$-ray tube at present in use.

It is possible that in a few years time the new discoveries of physics, the neutron and artificial radioactivity, will find a place in radiation therapy. Already, in the United States, neutron beams are available of sufficientlv high intensity to produce strong biological effects; their mode of action must differ in many respects from the radiations with which radiologists are familiar. Also it is now possible to obtain gamma-rays from artificial radioactive substances with energies far in excess of anything which radium emits. Radio-sodium, for example, disintegrates with emission of gammarays having energies in excess of 3 million volts. This substance has already been produced in weighable quantities; if it should prove possible to make it cheaply in bulk, it could be inserted daily into a radium unit of conventional design, and used for treatment in place of radium. All the knowledge which has been accumulated for radium beam therapy in the past could be brought to bear on the powerful new radiation.

In the meantime, it is of the greatest importance that there should be competent comparisons of the effects of radium and X-ray treatment, in which therapists, pathologists, biologists and physicists may make a thorough study of the results produced in living tissue, whether healthy or diseased, and explore to the full the new methods which the advance of physics is making available.

\title{
Biological Work of the Oxford University Expedition to North-East Land, I935-36
}

\author{
By D. B. Keith
}

$\mathrm{N}^{\mathrm{O}}$ ORTH-EAST LAND is the second largest island of the Spitsbergen archipelago and lies astride the parallel of $80^{\circ} \mathrm{N}$. Until a few years ago, it remained virtually an unknown land of evil repute. It was thought to lie outside the influence of the Gulf Stream and therefore to suffer from a far severer climate than the rest of Spitsbergen. The Oxford University Expedition, under the leadership of A. R. Glen, was the first expedition to winter in the country, and besides the radio research work, glaciology, survey and other activities of the expedition (see Nature, Jan. 2, p. 10), biological work was carried out through the year.

It may be said at the start that the animal life of North-East Land is incredibly meagre, and the reason for the great difference between there and the rest of Spitsbergen is the very much colder summer conditions prevailing on the island. The winter, too, is severer, but this has not the same effect on the animal life; but when it is realized that the temperature in the summer months very rarely rises above $40^{\circ} \mathrm{F}$., that snow storms are liable to occur at any time and that strong winds are almost continuous, it is not hard to see the reason for the paucity of animal life. It is probably not quite true to say that the Gulf Stream has no effect on North-East Land, for it now seems almost certain that the north-western coast does come under its influence, but its effect here is so small that the air temperature is invariably low and the weather usually windy and misty.
The difference between North-East Land and even the nearest areas of New Friesland is at once apparent in the vegetation. In North-East Land, the vegetation type most common is so open that it seems impossible to believe that biotic factors have played any part in its formation, whilst even in such areas as Treurenberg Bay and Lomme Bay, close plant communities are fairly extensive. In fact, the only areas in North-East Land where anything approaching close formations are to be found are in such places as the scree slopes below bird cliffs, areas (usually small islands) where colonies of eiders or terns are nesting, or, in a smaller way, round old nests of eiders, brent geese or glaucous gulls. Much of my biological work this summer was carried out in Murchison Bay, a large bay on the western coast, thickly dotted with islands, but one of which almost all the surrounding country is composed of dolomite. The sterility of the vegetation in such an area defies description. The rock weathers into fragments which are found covering great areas and lying loosely over the surface, entirely prohibiting any plant growth. Here and there a few specimens of Saxifraga oppositifolia or Papaver radicatum may have been able to take root; but it is almost true to say that the only places where plants are found are those where there has been manuring in some form or another.

My main work was a study of the birds, and here again the same may be said with regard to 